\title{
Current Trends in Technical and Vocational Education Research: A Meta-Analysis
}

\author{
Ruhizan M. Yasin ${ }^{1}$, Y. Faizal Amin Nur ${ }^{1}$, C. R. Ridzwan ${ }^{1}$, H. Tajul Ashikin ${ }^{1}$ \& R. Mohd Bekri ${ }^{1}$ \\ ${ }^{1}$ Faculty of Education, National Malaysia University, Bangi Selangor, Malaysia \\ Correspondence: Y. Faizal Amin Nur, Faculty of Education, National Malaysia University, Bangi Selangor, \\ Malaysia. Tel: 60-1-3725-2700. E-mail: faizaly@uthm.edu.my
}

Received: June 13, 2013 Accepted: August 12, 2013 Online Published: September 29, 2013

doi:10.5539/ass.v9n13p243 URL: http://dx.doi.org/10.5539/ass.v9n13p243

\begin{abstract}
The rapid development of world economy led to the development of physical and human capital. This development is supported through the provision of skilled human resources impetus towards the enhancement of social economic status of a country. This encourages academics conducting more research in the field of Technical and Vocational Education (TVE) to help improve the development and the formation of skilled workers. Current trends in research conducted around the world to the field of TVE can be used for smart partnerships between academics and policy shapers of TVE in the country. To achieve the goal, this article will discuss the current trends of research conducted through literature review. The survey, carried out will involve the use of meta-analysis using a variety of relevant peer reviewed professional journals. The findings show that current trends in the study of selected journal focused on three main areas of apprenticeship, measurement and evaluation and the use of Information and Communications Technology (ICT) in the TVE.
\end{abstract}

Keywords: apprenticeship, measurement and evaluation, ICT

\section{Introduction}

Technical and Vocational Education (TVE) is one branch of education offered at the present time. It was created to provide opportunities for students who have a tendency to science and technology education to meet the manpower needs of the industry. To realize technical education programs, many related programs have been created and offered. This training system has also been introduced at the secondary school level to the tertiary level. These efforts will enable potential students are trained to be professional workforce and semi-professionals in various fields of technology and engineering. Technical and vocational education is actually able to help school dropouts in education is academic, but has great potential to become excellent individuals in the areas of skills and thereby stimulating the economy as a whole.

A variety of emerging trends in the research field of TVE. The flow exist must be understood in depth impact on the existing system. In order to understand the profound impact on the emergence of new trends in this system, there is a need for a deeper exploration of global trends in terms of changes in technology, economic and social (Majumdar, 2009). This global trend has clearly given the implications of the system of TVE Asia Pacific in general and Malaysia in particular. Changes experienced at once has changed the and affected the TVE system as the implementation of Competency Based Assessment, Employability, work-based learning, apprenticeships and so on.

Therefore, the purpose of this analysis is to identify the current trends, the latest issues of choice and the needs of researchers in the field of research that has been published TVE. Synthesis of results from studies Rojewski, Asunda \& Kim (2008) showed that studied trends in TVE not comprehensive, just refer to some kind of journal in the last three years (2002 to 2004) as the Journal Career and Technical Education Research, Journal of Career and Technical Education, and the Journal of Industrial Teacher Education study involving America. This resulted in the analysis results do not reflect the overall global scenario that occurred in the TVE. Thus a meta-analysis of studies that refer various international journals and current is required to view trends and current issues at the global level in the TVE.

\section{Related Work}

The 43 articles synthesized in this research were published between 2007 and 2011. The researcher focused on 4 
main aspects: research methodology, apprenticeship training and skill development, assessment and evaluation, and the use of ICT in technical and vocational education (TVE).

The articles were obtained from refereed journal sources, including the Journal of Vocational Education and Training (JVET), Education and Training (E \& T), Journal of European Industrial Training (JEIT) and Evaluation \& Research in Education (E \& RE). Besides the 4 main journals stated above, a few articles published in the Journal of Industrial Teacher Education (JITE), British Dental Journal, Evaluation, International Journal of Vocational Education and Training (IJVET), Journal of Career and Technical Education (JCTE), Evaluation of Educational and Technical Structure at Vocational Schools, On the Horizon, Global Journal of Human Social Science Research, Turkish Online Journal of Education Technology (TOJET), British Journal of Educational Technology (BJET), and Procedia Social and Behavioral Sciences which discuss the issue of TVE were also included in the analysis.

\subsection{Evaluation of Content: Content Analysis}

The researcher developed a coding schedule, as suggested by Hutchinson \& Lovell (2004), as a guide for the analysis of each article's content. According to Rojewski, Asunda \& Kim (2008), the aspects that should be subjected to analysis are research characteristics, research type and design, main research topic, main data sources, and data analysis method. Therefore, the content analysis conducted in this research focused on four main themes: research method, research design, data sources, and research issues.

The Method section describes in detail how the study was conducted, including conceptual and operational definitions of the variables used in the study, different types of studies will rely on different methodologies; however, a complete description of the methods used enables the reader to evaluate the appropriateness of your methods and the reliability and the validity of your results, It also permits experienced investigators to replicate the study, If your manuscript is an update of an ongoing or earlier study and the method has been published in detail elsewhere, you may refer the reader to that source and simply give a brief synopsis of the method in this section.

\section{Results: Research Themes}

All journals used in this research are relatively representative of both conceptual and research papers. A critique of the 43 articles published in the span of 4 years (2007-2011) was conducted and the researches were consequently divided according to research methodology, design, data sources, and emerging themes. Table 1 exhibits the research methodology used in the 43 articles, including conceptual papers, quantitative method, qualitative method, and also mixed method. Data shows that $30.2 \%$ of the researchers in the sample chose to use the quantitative method, $27.9 \%$ used the mixed method, while $18.6 \%$, each, used the qualitative method and conceptual paper method, respectively. According to the researcher's analysis, $11.6 \%$ of the articles published in JVET were in the form of conceptual papers, $9.3 \%$ of the articles published by E \& RE chose to use the mixed method, while $4.7 \%$, each, of the articles published by $\mathrm{E} \& \mathrm{~T}$ and JEIT used the quantitative method, respectively.

Table 1. Number and percentage according to research methodology

\begin{tabular}{|c|c|c|c|c|c|c|c|c|c|c|c|c|}
\hline \multirow{3}{*}{ Methodology } & \multicolumn{10}{|c|}{ Journal } & \multirow{2}{*}{\multicolumn{2}{|c|}{ Total }} \\
\hline & \multicolumn{2}{|c|}{ JVET } & \multicolumn{2}{|c|}{$\mathrm{E} \& \mathrm{~T}$} & \multicolumn{2}{|c|}{ JEIT } & \multicolumn{2}{|c|}{$\mathrm{E} \& \mathrm{RE}$} & \multicolumn{2}{|c|}{ Others } & & 0 \\
\hline & $\mathrm{n}$ & $\%$ & $\mathrm{n}$ & $\%$ & $\mathrm{n}$ & $\%$ & $\mathrm{n}$ & $\%$ & $\mathrm{n}$ & $\%$ & & $\%$ \\
\hline Conceptual & 5 & 11.6 & 1 & 2.3 & - & - & - & - & 2 & 4.7 & 8 & 18.6 \\
\hline Quantitative & 4 & 9.3 & 2 & 4.7 & 2 & 4.7 & - & - & 5 & 11.6 & 13 & 30.2 \\
\hline Qualitative & 3 & 7.0 & 2 & 4.7 & - & - & - & - & 3 & 7.0 & 8 & 18.6 \\
\hline Mixed method & 2 & 4.7 & 2 & 4.7 & - & - & 4 & 9.3 & 4 & 9.3 & 12 & 27.9 \\
\hline Total & 14 & 32.6 & 7 & 16.4 & 2 & 4.7 & 4 & 9.3 & 14 & 32.6 & 43 & 100 \\
\hline
\end{tabular}

Table 2 further explains the aspect of research designs employed by the researchers. It was found that the survey design was used most commonly, amounting to $52.2 \%$ of the entire sample, while the least commonly used is the experimental design which only summed $2.6 \%$ of the sample. The case study design was used by $44.7 \%$ of researchers. The data also shows that eight articles (21\%) from the other journals category used the survey design, while seven (18.4\%) articles published by JVET used the case study design. Four articles (10.5\%) published in $\mathrm{E} \& \mathrm{~T}$ and $\mathrm{E} \& \mathrm{RE}$ adapted the use of the survey design. 
Table 2. Number and percentage according to research design

\begin{tabular}{|c|c|c|c|c|c|c|c|c|c|c|c|c|}
\hline \multirow{3}{*}{ Design } & \multicolumn{10}{|c|}{ Journal } & \\
\hline & \multicolumn{2}{|c|}{ JVET } & \multicolumn{2}{|c|}{$E \& T$} & \multicolumn{2}{|c|}{ JEIT } & \multicolumn{2}{|c|}{$E \& R E$} & \multicolumn{2}{|c|}{ Others } & 10 & 0 \\
\hline & $\mathrm{n}$ & $\%$ & $\mathrm{n}$ & $\%$ & $\mathrm{n}$ & $\%$ & $\mathrm{n}$ & $\%$ & $\mathrm{n}$ & $\%$ & & 10 \\
\hline Case study & 7 & 18.4 & 3 & 7.9 & - & - & 4 & 10.5 & 3 & 7.9 & 17 & 44.7 \\
\hline Survey & 3 & 7.9 & 4 & 10.5 & 1 & 2.6 & 4 & 10.5 & 8 & 21.0 & 20 & 52.5 \\
\hline Experimental & - & - & - & - & 1 & 2.6 & - & - & - & - & 1 & 2.6 \\
\hline Total & 10 & 26.3 & 7 & 18.4 & 2 & 5.2 & 8 & 21.0 & 11 & 28.9 & 38 & 98.8 \\
\hline
\end{tabular}

Table 3 shows the number and percentage of data sources used in the sample of articles. Based on an analysis of the journals, the data sources were classified into five main data collection methods: questionnaire, experiment, interview, document analysis, and observation.

Table 3. Number and percentage according to data sources

\begin{tabular}{|c|c|c|c|c|c|c|c|c|c|c|c|c|}
\hline \multirow{3}{*}{ Data source } & \multicolumn{10}{|c|}{ Journal } & \multirow{2}{*}{\multicolumn{2}{|c|}{ Total }} \\
\hline & \multicolumn{2}{|c|}{ JVET } & \multicolumn{2}{|c|}{$\mathrm{E} \& \mathrm{~T}$} & \multicolumn{2}{|c|}{ JEIT } & \multicolumn{2}{|c|}{$\mathrm{E} \& \mathrm{RE}$} & \multicolumn{2}{|c|}{ Others } & & \\
\hline & $\mathrm{n}$ & $\%$ & $\mathrm{n}$ & $\%$ & $\mathrm{n}$ & $\%$ & $\mathrm{n}$ & $\%$ & $\mathrm{n}$ & $\%$ & $\mathrm{n}$ & $\%$ \\
\hline Questionnaire & 3 & 5.5 & 3 & 5.5 & 1 & 1.8 & 2 & 3.6 & 8 & 14.6 & 17 & 31.0 \\
\hline Experiment & - & - & - & - & 1 & 1.8 & 1 & 1.8 & 2 & 3.6 & 4 & 7.2 \\
\hline Interview & 6 & 10.0 & 4 & 7.3 & - & - & 4 & 7.3 & 4 & 7.3 & 18 & 31.9 \\
\hline $\begin{array}{l}\text { Document } \\
\text { analysis }\end{array}$ & 8 & 14.6 & - & - & - & - & 1 & 1.8 & 6 & 10.0 & 15 & 26.4 \\
\hline Observation & 1 & 1.8 & - & - & - & - & - & - & - & - & 1 & 1.8 \\
\hline Total & 18 & 31.9 & 7 & 12.8 & 2 & 3.6 & 8 & 14.5 & 20 & 35.5 & 55 & 98.3 \\
\hline
\end{tabular}

The total (\%) column cannot amount to $100 \%$ due to approximation error.

Data shows that $31.0 \%$ of the researches employed the use of questionnaires and $31.9 \%$ used interviews to collect data. 26.4\% researches used secondary sources i.e. document analysis to gather data. Experiments (7.2\%) and observation (1.8\%) showed the lowest percentage of use. Eight articles (14.6\%) from the 'other' journals used questionnaires, while $6(10.0 \%)$ used document analysis for data collection. Eight $(14.6 \%)$ articles published in JVET used document analysis while six (10.0\%) used interviews. Meanwhile, four (7.3\%) articles published, each, in E \& T and E \& RE utilized interviews as data collection sources.

Table 4 shows the number and percentage of issues that emerged from the three themes in the published research. A synthesis of the 43 articles discussing TVE showed nine issues which were frequently studied by researchers in the span of four years (2007-2011). The issues were studied according to the current trends or problems which frequently surfaced in the span of the four years; they can be divided into three main themes i.e. apprenticeship, evaluation, and ICT.

The data shows that 24 articles discussed the theme of apprenticeship, 12 discuss the theme of evaluation, and seven discuss the theme of ICT. Under the theme of apprenticeship, four frequently discussed issues emerged: the issue of apprenticeship models (41.0\%), evaluation of apprenticeship (37.5\%), discussion of apprenticeship $(16.6 \%)$ and marketability of apprentices $(4.1 \%)$. For the theme of evaluation, three issues were frequently discussed: the issue of competency evaluation $(50.0 \%)$, effectiveness of programs $(41.6 \%)$ and development of instruments (8.4\%). Finally, under the theme of ICT, two issues emerged as being frequently discussed: the issue of the implementation of ICT in TVE (71.4\%), and ICT in the special education stream of TVE (28.6\%). 
Table 4. Number and percentage of research issues

\begin{tabular}{lll} 
Theme and Research Issues & Total & \\
& $\mathrm{N}$ & $\%$ \\
\hline APPRENTICESHIP & 1 & 4.1 \\
Marketability & 10 & 41 \\
Apprenticeship models & 9 & 37.5 \\
Apprenticeship evaluation & 4 & 16.6 \\
Discussion of apprenticeship & $\mathbf{2 4}$ & $\mathbf{1 0 0}$ \\
Total & 5 & 41.6 \\
EVALUATION & 6 & 50.0 \\
Effectiveness of program & 1 & 8.4 \\
Competency evaluation & $\mathbf{1 2}$ & $\mathbf{1 0 0}$ \\
Instrument development & & \\
Total & & 71.4 \\
ICT & 5 & 28.6 \\
Implementation of ICT in TVE & 2 & $\mathbf{1 0 0}$ \\
ICT in the special education stream of TVE & $\mathbf{7}$ \\
Total & & \\
\hline
\end{tabular}

\section{Discussion}

Results of data analysis show that the current research trend in this field is the use of the quantitative method $(30.2 \%)$ as it is most frequently employed in the articles sampled in this research. In terms of research design, researchers seem to prefer the use of the survey method and much of their data was collected using interviews. In comparison to this finding, a research by Rojewski et al., (2008) showed that researchers of TVE frequently adapt the use of the quantitative method in their research; this is similar to the trend shown in the current research. However, in terms of research design, Rojewski et al., (2008) stated that researchers prefer the correlation design and use document analysis for data collection, which is distinct from the survey method and interview sources favoured by the researchers studied in the current research. This comparison shows that the TVE field of research has experienced a few changes.

The change in trends is affected by the times as the methods used in the research must be adapted to the contextual scenario of TVE. Besides that, a research design should be chosen by virtue of its characteristics and how it contributes to the research (Cohan, Manion \& Morrison, 2011). The analysis results show that the issues discussed focus on apprenticeship, evaluation, and ICT in TVE.

\subsection{Apprenticeship in TVE}

Apprenticeship is an important topic in the field of TVE because it is crucial in the preparation of skilled human labour. Most researches focus on European countries, especially Germany and Australia, as they have internationally acclaimed apprenticeship systems. Much of the research published in professional journals focus on studies of apprenticeship models and their connection to apprenticeship systems (Guile, 2011; Smith, 2011; Lang, 2011; Jull, 2011; Warm, 2011; Sligo, 2011; Mazuki, 2011; Philip, 2011; Thomas, 2011; Maarif, 2011). Besides that, there are also researches that evaluate the apprenticeship systems in countries such as Canada (Meredith, 2011), Germany (Christian, 2010), the Netherlands (Cyrille, 2011), and also certain industrial areas (Cindy, 2011; Zoharah et al., 2011; Hair et al., 2011).

Additionally, there are researches that discuss existing apprenticeship systems using past research and government reports. This type of research is conducted for the purpose of information-sharing with peers; among these researches are those done by Fuller (2011), Gunter (2011), Terence (2011), and Lorenz (2011). These studies can help other researchers understand the apprenticeship systems implemented in the place in which the research was conducted and the findings of these researches are commonly discussed among TVE academicians. 


\subsection{Evaluation in TVE}

In order to understand the vast effects of the trends surrounding TVE systems in this region, a deeper study of the global technological, economical, and social trends must be conducted (Majumdar, 2009). Global trends clearly shape TVE in the Asia-Pacific region because the increase in institutional and program competency and effectiveness allows TVE to react to industrial needs, observational support, suitable evaluation, and guarantee of quality (Majumdar, 2009).

Issues on evaluation and certification are prolific in Southeast Asia; research has shown that focus is given not only to methods of student evaluation but also steps that must be taken towards the accreditation of certificates (Omar \& Paryono, 2008; Rojewski, Asunda \& Kim, 2008). This is supported by the trends and issues published in TVET in the Asia-Pacific region, based on the Colombo Plan Staff College (CPSC) (Majumdar, 2009), showing that issues related to assessment and evaluation are critical issues in TVE systems.

Competency evaluation is the most commonly discussed issue in the articles used as the sample for this research (Battista, Palomba \& Vergani, 2009; Schaap, Schaaf \& Bruijn, 2011; Ion \& Cano, 2011; Koopman, Teune \& Beijaard, 2008; Nafukho, Graham \& Kacirek, 2009; Mamaqi, Miguel \& Olave, 2011). These researches are more focused on identifying the levels of implementation of competency-based achievement evaluations among lecturers and students in educational systems (Ion \& Cano, 2011; Schaap, 2011; Nafukho, 2009). According to these studies, the implementation of competency-based evaluations can only be considered successful if all competency evaluation concepts are performed i.e. lecturer participation, students, and evaluation techniques.

Issues related to program effectiveness are also frequently discussed in the articles (Adiguzel \& Cardak, 2009; Bullock, Falcon, Mehra \& Stearns, 2010; Kagaari, 2007; Tanrisever \& Erişen, 2009; Uzmano, 2010). The effectiveness of a program is dependent on factors such as infrastructure, experienced teaching staff, acceptance, and teaching staff's preparation and understanding of the evaluation system that is to be implemented (Bullock et al., 2010; Kagaari, 2007; Tanrisever \& Erişen, 2009). Besides that, the content of the program and module being implemented must be parallel with industrial and employee demands so that there is no mismatch when students seek employment. This is supported by Uzmanoglu (2010) and Adiguzel \& Cardak (2009) who state that cooperation between school authorities and industry is paramount in giving students relevant exposure and also in the construction of industry-based curriculum.

Issues related to instrument development have been least explored. Only one study was found in the sample of articles used in this research; the research was conducted by Ansah (2010) who developed an instrument to improve the quality of evaluation. The development of these instruments is crucial as they ensure the quality of evaluation programs, especially newly implemented programs. This is because there is no 'one size fits all' solution in terms of evaluation systems for education; the type of system that should be used depends on the environment and implementation approach (Ansah, 2010).

Therefore, it can be concluded that evaluation is an important factor in the production of quality workforce. The issue of assessment and evaluation is vital in the shaping of sustainable quality human capital for the improvement of society (Majumdar, 2009). This concept of sustainability is the main foundation of TVE in its vision of enhancing the quality of employee lifestyle and, consequently, eradicating the problem of unemployment and social backwardness (Minghat \& Yasin, 2010).

\subsection{ICT in TVE}

ICT issues in TVE focus on aspects related to the implementation of ICT in the teaching and learning process and research has shown that the use of ICT in these fields have been shown to be limited (UNESCO - UNEVOC, 2010; Papua New Guinea Department of Education, 2004; Jinnah et al., 2011; Athanase et al., 2008; Robert, 2011; Mumcu \& Usluel, 2010). Most of the researches conducted on this issue focus on countries like Georgia, Papua New Guinea, Southeast-Asian countries, African countries such as Nigeria, and Turkey. There are also researches that discuss issues concerned with the implementation of ICT in the teaching and learning process of technical subjects for special education stream students in Finland and Malaysia (Starcic \& Niskala, 2010; Hadi et al., 2010). According to these researchers, the integration of ICT in this stream of education must be drawn attention to as it plays a pivotal role in determining the academic achievement of special education students. The applications used in the integration of ICT in TVE have also been studied by researchers such as Arh et al., (2009) who discuss the development of TVE based on approaches utilizing community portals that focus on innovation transfer and lifelong learning in Europe. Besides that, Starcic \& Niskala (2010) created the SEVERI teaching and learning system which is an educational system for special education in Finland, Lithuania and Hungary. The system applies ICT through the use of the e-learning concept and it tremendously helps students who face problems with their physicality, communication, emotion, and cognition which consequently causes difficulties 
in reading and writing.

Based on the articles studied in this research, the integration of ICT in TVE clearly benefits both the teacher and student. Technology has become essential in the evolution of TVE as it not only saves time and energy, but also makes the search for information much more effortless (UNESCO, 2008). Undoubtedly, ICT offers remarkable potentials towards adding value to TVE; teachers and students can interact and share information amongst themselves and this can improve the quality of teaching and learning in educational institutions (Jinnah et al., 2011; Maclean, 2009; Neal, 2011; Robert, 2011). However, though the importance of ICT in TVE cannot be disputed, the implementation of ICT in the classroom is difficult due to financial, technological, and skill constraints; this is supported by Neal (2011) and UNESCO (2008) who found that among the challenges of implementing such a proposal in schools are the technological usage, financial constraints, new skills that teachers and students are required to learn, and requisite infrastructure needed to ensure that information can be accessed and sent properly. In conclusion, the development of high-quality and up-to-date ICT-based teaching products is the main challenge in today's TVE field.

\section{Conclusion}

This meta-analysis research was conducted to identify the trends and current issues in TVE which surfaced in the span of five years (2005 until 2010). Analysis results show that the issues most commonly discussed are apprenticeship, evaluation, and use of ICT in TVE; from these three issues, apprenticeship was most frequently studied. Results also show that the quantitative research method and survey research design were used the most, while interviews were the most commonly used data source as compared to the questionnaire and document analysis methods. As a consequence of the emerging issues in TVE i.e. apprenticeship, evaluation, and ICT in TVE, educational institutions concerned with TVE must empower it by encouraging more research in the field so as to fulfill current and future and demands.

\section{References}

Adiguzel, O. C., \& Cardak, C. S. (2009). An Evaluation of the "Computer Technology and Programming" Curriculum in the Vocational Higher Education System in Turkey. Journal of Industrial Teacher Education, 45(3), 61-83.

Ansah, F. (2010). Designing Self-Evaluation Instruments for Academic Programmes: Lessons and Challenges. Evaluation \& Research in Education, 23(2), 77-90. http://dx.doi.org/10.1080/09500791003717238

Arh, T., Pipan, M., Blažič, B. J., Debevc, M., \& Peternel, M. M. (2009). Enhancing the E-Learning in Vocational Education and Training with Vet Community Portal. Proceedings of the 8th WSEAS International Conference on E-Activities and information security and privacy, 99-104.

Athanase, N., Jiang, C., Li, H., \& Chen, Z. (2008). Organizational e-learning strategies for technical and vocational education and training (TVET) in Sub-Sahara Africa. International Conference Computer on Science and Software Engineering, 2008, 267-270. http://dx.doi.org/10.1109/CSSE.2008.1495

Battista, G. D., Palomba, L., \& Vergani, A. (2009). Evaluating the Quality of Italian Local Vocational Training Systems: Towards a Sustainable and Shared Self-Assessment Tool. Evaluation, 15(2), 185-203 \& 249-250.

Becker, K., \& Park, K. (2011). Effects of integrative approaches among science, technology, engineering, and mathematics (STEM) subjects on students' learning: A preliminary meta-analysis. Journal of STEM Education, 12(5\&6), 23-37.

Bullock, A., Falcon, H., Mehra, S., \& Stearns, K. (2010). An Evaluation of a Vocational Training Scheme for Dental Therapists (Tvt). British Dental Journal, 209(6), 295-300. http://dx.doi.org/10.1038/sj.bdj.2010.818

Cohen, L., Manion, L., \& Morrison, K. (2011). Research Method in Education (7th Ed.). London \& New York: Routledge

Cyrille, A. C., Bragt, V., Anouke, W. E. A., Bakx, P. J., Teune, T. C. M. B., \& Marcel, A. C. (2011). Why students withdraw or continue their educational careers: a closer look at differences in study approaches and personal reasons. Journal of Vocational Education \& Training, 63(2), 217-233. http://dx.doi.org/10.1080/13636820.2011.567463

Dahar, M. A., \& Ruhizan, M. Y. (2010). Sustainable Framework for Technical and Vocational Education in Malaysia. Procedia - Social and Behavioral Sciences, 9(0), 1233-1237.

Deissinger, T., Heine, R., \& Ott, M. (2011). The dominance of apprenticeships in the German VET system and its implications for Europeanisation: a comparative view in the context of the EQF and the European LLL strategy. Journal of Vocational Education \& Training, 63(3), 397-416. http://dx.doi.org/10.1080/13636820.2011.569089 
Fuller, A., \& Unwin, L. (2011). Apprenticeship as an evolving model of learning. Journal of Vocational Education \& Training, 63(3), 261-266. http://dx.doi.org/10.1080/13636820.2011.602220

Glass, G. V. (1976). Primary, secondary, and meta-analysis of research. Educational Researcher, 5, 3-8. http://dx.doi.org/10.3102/0013189X005010003

Grollmann, P., \& Rauner, F. F. (2007). Exploring innovative apprenticeship: quality and costs. Education \& Training, 49(6), 431-446. http://dx.doi.org/10.1108/00400910710819091

Guile, D. (2011). Apprenticeship as a model of vocational 'formation' and 'reformation': the use of Foundation Degrees in the aircraft engineering industry. Journal of Vocational Education \& Training, 63(3), 451-464. http://dx.doi.org/10.1080/13636820.2011.600835

Hadi, A., Yusop, M., Mohamad, B., \& Jaafar, M. S. A. (2010). Study of information and communication technology (ICT) usage in technical and vocational special education programme. Global Journal of Human Social Science Research, 10(1), 35-43.

Hogarth, T., Gambin, L., \& Hasluck, C. (2012). Apprenticeships in England: what next? Journal of Vocational Education \& Training, 64(1), 41-55. http://dx.doi.org/10.1080/13636820.2011.590221

Ion, G., \& Cano, E. (2011). Assessment Practices at Spanish Universities: From a Learning to a Competencies Approach. Evaluation \& Research in Education, 24(3), 167-181. http://dx.doi.org/10.1080/09500790.2011.610503

Jinnah, M. A., Abdullah-Al-Mamun, M., Khan, M. S. H., \& Hasan, M. (2011). ICT in vocational teaching/learning and research in southeast asian countries: A case of Bangladesh. International Journal of Vocational and Technical Education, 3(2), 20-28.

Johnson, B., \& Christensen, L. (2008). Educational research: Quantitative, qualitative, and mixed approaches. Thousand Oaks, CA: Sage.

Jusoh, M., Simun, M., \& Chong, S. C. (2011). Expectation gaps, job satisfaction, and organizational commitment of fresh graduates:Roles of graduates, higher learning institutions and employers. Education \& Training, 53(6), 515-530. http://dx.doi.org/10.1108/00400911111159476

Juul, I., \& Jørgensen, C. H. (2011). Challenges for the dual system and occupational self-governance in Denmark. Journal of Vocational Education \& Training, 63(3), 289-303. http://dx.doi.org/10.1080/13636820.2011.560393

Kagaari, R. K. J. (2007). Evaluation of the Effects of Vocational Choice and Practical Training on Students' Employability. Journal of European Industrial Training, 31(6), 449-471. http://dx.doi.org/10.1108/03090590710772640

Koopman, M., Teune, P., \& Beijaard, D. (2008). How to Investigate the Goal Orientations of Students in Competence-Based Pre-Vocational Secondary Education Choosing the Right Instrument. Evaluation \& Research in Education, 21(4), 318-334. http://dx.doi.org/10.1080/09500790802204604

Lang, M. (2010). Can mentoring assist in the school-to-work transition? Education \& Training, 52(5), 359-367.

Lassnigg, L. (2011). The 'duality' of VET in Austria: institutional competition between school and apprenticeship. Journal of Vocational Education \& Training, 63(3), 417-438. http://dx.doi.org/10.1080/13636820.2011.590220

Livingston, P. K. (2008). A meta-analysis of the effectiveness of anti-bullying programs on students. Unpublished doctoral dissertation, Texas A \& M University.

Maclean, R. (2009). The importance of secondary education and TVET. In E. Tokai \& J. Teasdale (Eds.), The role of TVET in Pacific secondary schools: New visions, new pathways, 31-40.

Majumdar, S. (2009). TVET response to global trends in the Colombo plan region. Paper presented at the Conference Proceedings of International Conference on Harnessing Qualifications Framework towards Quality Assurance in TVET, Manila, Philippines.

Mamaqi, X., Miguel, J., \& Olave, P. (2011). Evaluation of the Importance of Professional Competences: The Case of Spanish Trainers. On the Horizon, 19(3), 174-187. http://dx.doi.org/10.1108/10748121111163887

Meredith, J. (2011). Apprenticeship in Canada: where's the crisis? Journal of Vocational Education \& Training, 63(3), 323-344. http://dx.doi.org/10.1080/13636820.2011.570453

Mumcu, F. K., \& Usluel, Y. K. (2010). ICT in vocational and technical schools: teachers'instructional, managerial and personal use matters. Turkesh Online Journal of Education Technogy, 9(1), 98-106.

Nafukho, F. M., Graham, C. M., \& Kacirek, K. (2009). Education Service Agency Audits: Reinforcing the Need 
for Systematic Evaluation. International Journal of Vocational Education and Training, 17(2), 19.

Neal, T. (n. d.). Open and Flexible Technical and Vocational Education and Training in Commonwealth Pacific Countries. Open Learning for an Open World: Reflections on Open and Distance Learning and Teaching at the Open Polytechnic of New Zealand, 264.

Omar, M. S. H., \& Paryono. (2008). Current Trends and Issues in VTET: Seameo Voctech's Response. SEAVERN Journals, 1(1), 1-18.

Omar, Z., Krauss, S. E., Sail, R., \& Ismail, I. A. (2011). Exploring career success of late bloomers from the TVET background. Education \& Training, 53(7), 603-624. http://dx.doi.org/10.1108/00400911111171995

Papua New Guinea Department of Education. (2004). Achieving a better future: A National Plan for Education 2005-2014. Retrieved December $\quad 3, \quad$ from http://paddle.usp.ac.fj/collect/paddle/index/assoc/png040.dir/doc.pdf

Poortman, C. L., Illeris, K., \& Nieuwenhuis, L. (2011). Apprenticeship: from learning theory to practice. Journal of Vocational Education \& Training, 63(3), $267-287$. http://dx.doi.org/10.1080/13636820.2011.560392

Rahim, M. S., \& Alavi, K. (2010). Social skills and social values training for future k-workers. Journal of European Industrial Training, 34(3), 226-258. http://dx.doi.org/10.1108/03090591011031737

Rasul, M. S., Ismail, M. Y., Ismail, N., Rajuddin, R., \& Rauf, R. A. (2009). Aspek Kemahiran 'Employability' yang Dikehendaki Majikan Industri Pembuatan Masa Kini. Jurnal Pendidikan Malaysia, 34(2), 67 - 79.

Robert, O. O. (2011). Information and communication technology awareness among technical college teachers in Benue State, Nigeria. International Journal of Vocational and Technical Education, 3(6), 75-80.

Rojewski, J. W., Asunda, P., \& Kim, S. J. (2008). Trends in Career and Technical Education Research. Journal of Career and Technical Education, 24(2), 57.

Schaap, H., Schaaf, M. F. V. D., \& Bruijn, E. D. (2011). Development of Students' Personel Professional Theories in Senior Secondary Vocational Education. Evaluation \& Research in Education, 24(2), 81-103. http://dx.doi.org/10.1080/09500790.2010.550280

Schmidt, C. (2010). Vocational education and training (VET) for youths with low levels of qualification in Germany. Education \& Training, 52(5), 381-390.

Schmidt, M., Easter, M., Jonassen, D., Miller, M., \& Ionas, G. (2008). Preparing the twenty-first century workforce: the case of curriculum change iradiation protection education in the United States. Journal of Vocational Education \& Training, 60(4), 423-439. http://dx.doi.org/10.1080/13636820802591780

Sligo, F., Tilley, E., \& Murray, N. (2011). Do apprentices' communities of practice block unwelcome knowledge? Education \& Training, 53(4), 297-309.

Smith, E., Comyn, P., Kemmis, R. B., \& Smith, A. (2011). Australian employers' adoption of traineeships. Journal of Vocational Education \& $\quad$ Training, $263-375$. http://dx.doi.org/10.1080/13636820.2011.559267

Spark, A., Ingram, H., \& Philips, S. (2009). Advanced entry adult apprenticeship training scheme: a case study. Education \& Training, 51(3), 190-202. http://dx.doi.org/10.1108/00400910910960722

Starcic, A. I., \& Niskala, M. (2010). Vocational students with severe learning difficulties learning on the Internet. British Journal of Educational Technology, $41(6), \quad$ 155-159. http://dx.doi.org/10.1111/j.1467-8535.2010.01128.x

Tanrisever, S., \& Erişen, Y. (2009). The Evaluation of Modular Education Programmes Developed for the "Modernization of Vocational and Technical Education Project". Procedia Social and Behavioral Sciences, 1(1), 1384-1388. http://dx.doi.org/10.1016/j.sbspro.2009.01.244

Taylor, A., \& Freeman, S. (2011). 'Made in the trade': youth attitudes toward apprenticeship certification. Journal of Vocational Education \& $\quad$ Training, 63(3), http://dx.doi.org/10.1080/13636820.2011.570455

UNESCO. (2008). Ubiquitous ICT for Sustainable Education and Cultural Literacy Report. German : UNESCO.

UNESCO-UNEVOC. (2010). International Expert Meeting ICTs to strengthen TVET in Georgia Meeting Report. Born Germany.

Uzmanoğlu et al. (2010). Evaluation of educational and technical structure at vocational schools. Procedia-Social and Behavioral Sciences, 2(2), 3447-3451. http://dx.doi.org/10.1016/j.sbspro.2010.03.532

Virolainen, M. H., Stenström, M. L., \& Kantola, M. (2011). The views of employers on internships as a means of 
learning from work experience in higher education. Journal of Vocational Education \& Training, 63(3), 465-484. http://dx.doi.org/10.1080/13636820.2011.580360

Walden, G., \& Troltsch, K. (2011). Apprenticeship training in Germany-still a future-oriented model for recruiting skilled workers? Journal of Vocational Education \& Training, 63(3), 305-322. http://dx.doi.org/10.1080/13636820.2011.570454

Warmington, P. (2011). Divisions of labour: activity theory, multi-professional working and intervention research. Journal of Vocational Education \& $\quad$ Training, $\quad 63(2), \quad$ 143-157. http://dx.doi.org/10.1080/13636820.2011.561930

\section{Copyrights}

Copyright for this article is retained by the author(s), with first publication rights granted to the journal.

This is an open-access article distributed under the terms and conditions of the Creative Commons Attribution license (http://creativecommons.org/licenses/by/3.0/). 